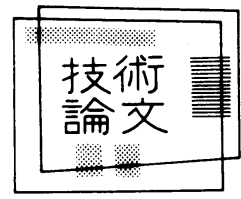

\title{
ヒートパイプ冷却による排気弁の 高温腐食対策*
}

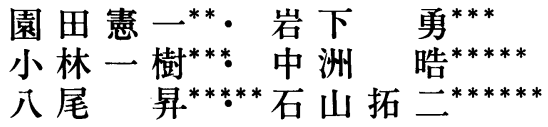

Heat Pipe Cooling of Exhaust Valves for Improvement in Hot Corrosion Resistibility

By Kenichi Sonoda, Isamu Iwasita, Kazuki Kobayasi

Hirosi Nakasu, Noboru Yao, and Takuji Isiyama

This paper discribes a new method of cooling exhaust valves for marine diesel engines. The principle of heat pipe is employed to give highly efficient cooling and to improve the durability of valves under corrosive operating conditions. Test valves for two types of marine diesel engines, V52/55A and L60MC, are developed and tested to investigate mainly their performance of heat transfer.

Test results show a sufficient heat transfer capability of the cooled valves without any special design of valve cages, and accordingly a low temperature level at the valve disks. By optimizing the amount and distribution of heat input to the cooling chamber in the valve cone, the valve can be given adequate temperature at any portion, and can be prevented from corrosion.

\section{1. まえがき}

2 サイクル機関においてユニフロー掃気方式が主流と なった現在，排気弁の耐久性向上は 4 サイクル，2サイ クルを問わず, 舶用ディーゼル全般に渡る重要課題とな っている.ささらに, 近年の熱効率向上のための諸対策の 施行や，燃料油の低質化は排気弁の作動環境をますます 苛酷なあのとしており, 耐久性向上のための研究開発を 尚一層強力に進める必要があると思われる.

排気弁の損傷は, 弁フェース (シート) の吹抜け, 傘 部及び首部の高温腐食, 弁軸部, 弁案内, 弁ヶージなど の低温腐食が主な原因で ${ }^{1}$, 弁各部の温度及び燃料油中 に含まれるV，Sや潤滑油中の Ca による燃焼生成物の 量が重要な因子であると言われている。これらの損傷を 防止し, 弁の耐久性を向上させるための対策としては材 質面での研究開発が盛んで, すぐれた特性を持つ母材又 は盛り金材が開発されている2．一方では弁の冷却強化

\footnotetext{
* 原稿受付 平成元年 4 月 7 日

第25回特別基金講演（昭和63年12月 1 日）

** 正会員川崎重工業技術研究所（神戸市中央区東川 崎町 $3-1-1)$

*** 川崎重工業，宇宙開発室（同上）

**** 川崎重工業鉄構 - 機器事業部 (同上)

***** 正会員 川崎重工業原動機事業部（同上）

****** 正会員 徳島大学 (德島市南常三島町 2-1)
}

Journal of the M.E.S.J., Vol. 24, No. 9
のため, 主として弁座冷却の改善が行われ, 中低速機関 の殆どが水冷式弁座を備えるようになっている，しかし， 高温腐食と低温腐食を同時に防止するために, 弁各部の 温度を適切な範囲に制御することは必ずしも容易でない。 このような点を改善するため, 本研究では新しい原理に 基づく冷却式排気弁を開発試作し, 実機関による性能試 験を行ったのでその結果を報告する.

\section{2.ヒートパイプ冷却排気弁}

図 1 にヒートパイプ冷却式排気弁の作動原理を示す. 弁本体は，弁傘から軸に渡って内部に冷却室が設けられ， ここに冷却媒体を注入した後残りの空間を高真空に排気 して密封する. シリンダ内の高温ガスによって弁底部が 加熱されると, 冷却室底部において媒体が蒸発して蒸気 となり, 軸部空間を上昇する.この時, 弁軸上部を冷却 してやれば, 軸内面で蒸気が凝縮して液体となり,これ が壁面にそって還流して底部に戻る. 冷却媒体は密閉空 間内で相変化を行いつつ偱環するだけで失われることが ないため,この動作は連続的に繰り返され, その間冷却 室底部で蒸発潜熱として蒸気に与えられた熱量が, 軸内 面で凝縮によって放出されるので, 一方向に熱輸送が行 われる.

良く知られているようにこのようなヒートパイプに よる熱輸送は, 潜熱に基づいておこなわれ, しか屯冷却 室内から媒体蒸気と液以外の物を排除したことによって 
高い熱伝達効率が得られるため, 限られたサイズで大き な熱量を輸送できる可能性がある.

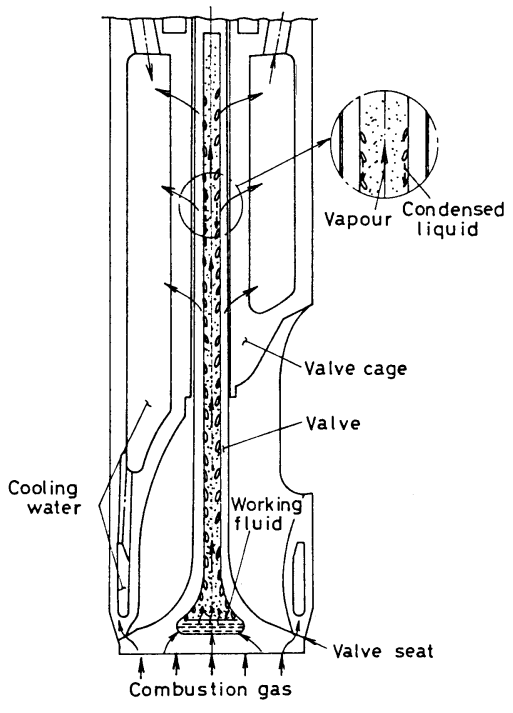

図 1 ヒートパイプ冷却式排気弁

\section{3. 供試排気弁及び試験機関}

前述のようなヒートパイプの優れた熱輸送性能を十分 利用するためには, 燃焼ガスの温度や熱伝達率, 弁座及 び弁軸冷却の条件などの外部的条件と, 弁体の内部的な 熱伝達条件が明らかで，これらのマッチングが取れてい る必要がある. 試作弁の設計にあたっては, 冷却室形状, 寸法や媒体の種類, 封入量等の主要な諸元を, 推定した 熱伝達条件を用いてきめておき，まず弁本体及び弁ケー ジのみを用いたモデルテストを実施して試作弁の作動範 囲や各部熱伝達条件をある程度確認したうえで, 実機試 験に供した. 試作弁の設計及びモデルテストについては, 別報に譲るとして，以下では実機テストに関する事項の みを報告する.

表 1 は, 対象とした試験機関の主要目を示す.V 52/ 55Aは 4 サイクル機械駆動 4 弁式 $\mathrm{V}$ 型 2 シリンダ機関で, 片側シリンダのみを作動させて試験し, 弁の装着方向は 垂直方向から 22.5 度傾く.L60MCは 2 サイクル油圧駆 動 1 弁式 5 シリンダ機関で, 特定のシリンダのみを対象 として試験し，弁の装着方向は垂直である.

図 2 は, 供試排気弁の外形を（同一縮尺），また表 2 は供試弁の主要目を示す。試作弁はいずれも内壁にウイ ック構造を持たず，いわゆるウイックレスヒートパイプ 又は二相サーモサイフォンと呼ばれる, 重力によって液 還流を行う最も単純な構造を持つ形式を用いた。冷却室 底部面積は，ヒートパイプに流入する熱量に関係し，作 動（蒸気）温度に影響する屯のと予想されるので，52/ $55 \mathrm{~A}$ についてはその影響度を見るために二種類の底部直 径 $\left(\mathrm{d}_{2}\right)$ を持つ弁 $(70 \mathrm{H}, 50 \mathrm{H})$ を用意した. $60 \mathrm{MC}$ のあの
表 1 試験機関主要目

\begin{tabular}{|c|c|c|}
\hline & V52/55A & L6OMC \\
\hline Type & 4-stroke V & 2-stroke \\
\hline Cylinder bore & 520 & 600 \\
\hline Piston stroke & 550 & 1944 \\
\hline Number of cylinder & 1 & 5 \\
\hline Out put & 776 & $1176^{*}$ \\
\hline Engine speed $\mathrm{rpm}$ & 450 & $95^{*}$ \\
\hline B.M.E.P. & 1.77 & $1.35^{\star}$ \\
\hline Charge air & blower & turbocharge \\
\hline Valve drive & mechanical & hydraulic \\
\hline
\end{tabular}

* Derating spec.
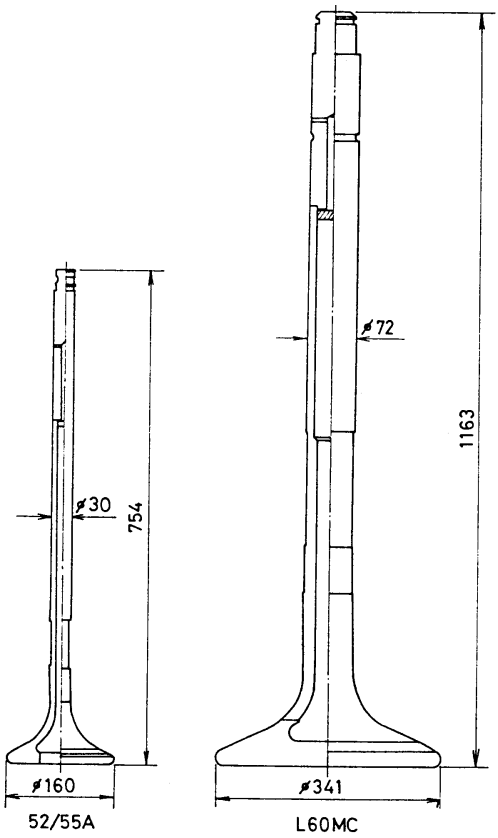

図 2 供試排気弁

表 2 供試排気弁主要目

\begin{tabular}{|c|c|c|c|c|}
\hline & \multicolumn{2}{|c|}{$52 / 55 A$} & L6OMC & \\
\hline Type & \multicolumn{2}{|c|}{$\begin{array}{lll}70 \mathrm{H} & 50 \mathrm{H} \\
\end{array}$} & type A & \\
\hline $\begin{array}{l}\text { Valve disc dia. } \\
\text { D,mm }\end{array}$ & \multicolumn{2}{|c|}{160} & 341 & \\
\hline $\begin{array}{l}\text { Valve stem dia. } \\
D_{2} \text { mm }\end{array}$ & \multicolumn{2}{|c|}{30} & 72 & $=\| \frac{D_{2}}{d_{2}}$ \\
\hline Material (base) & \multicolumn{2}{|c|}{ SUH31 } & SUH 31 & \\
\hline (armour) & \multicolumn{2}{|c|}{ 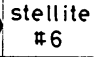 } & $\begin{array}{c}\text { colmonoy } \\
6\end{array}$ & \\
\hline $\begin{array}{l}\text { Chamber dia. } \\
\text { (disc) di mm }\end{array}$ & 70 & 50 & 120 & $\frac{d_{1}}{D_{1}^{-1}}$ \\
\hline (stem) & \multicolumn{2}{|c|}{16} & $38(50 *)$ & \\
\hline Working fluid & \multicolumn{2}{|c|}{ water } & water & \\
\hline
\end{tabular}

* cooling zone

は概略 $50 \mathrm{H}$ に相当する寸法とした.

冷却媒体としては, 予想される作動温度範囲 473〜 $573 \mathrm{~K}\left\{200 \sim 300^{\circ} \mathrm{C}\right\}$ に適する作動液，水銀，ダウサム 
$\mathrm{A}$, 水等の内, 取り扱いの容易さや, 密度, 蒸気潜熱な ぞの物性值が優れている点を重視して, 精製水を選定し た. 弁本体の材質は，主として組み立て時の溶接性を考 慮していずれもSUH 31 相当とし, 肉盛り材としてはそ れぞれの弁に標準的なものとした. 冷却媒体と，これら

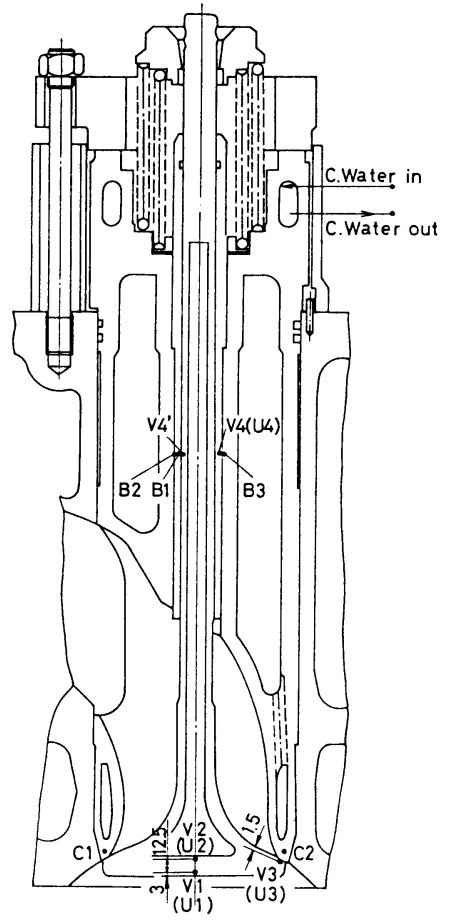

困 3 (1) 弁の装着状況と計測点 $(52 / 55 \mathrm{~A})$

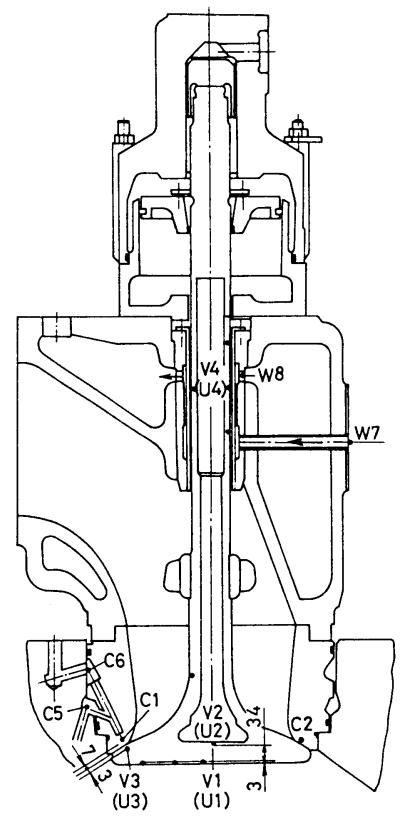

図 3 (2) 弁の装着状況と計測点 ( L 60 MC )
の弁材質との適合性については従来寿命テストの例がな いため, 今後確認を要するものと思われる.

図 3 は, 供試弁の装着状況を示しており, 弁座及び弁 軸冷却の状況が図示されている. 図から分かるように, 旧来の弁座冷却はそのままに，ヒートパイプ冷却をこれ に付け加える形とした．今回の試験では，弁本体以外の 構造を大幅に変更しないで冷却強化を行うことを前提と したが，ヒートパイプによって弁軸へ輸送される熱量を 効果的に放熱させる必要から, 弁軸冷却部に若干の変更 を施した．すなわち $52 / 55 \mathrm{~A} て ゙ は$ 低温腐食防止のために 設けられた弁案内ブッシュと弁ケージとの隙間を廃止し，

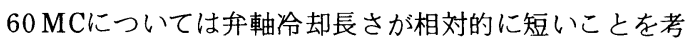
慮して, 弁案内ブッシュの外周に直接冷却水を導入する 構造とした.

\section{4. 試験及び計測方法}

試験計測は機関回転数及び負荷を理論舶用特性に従っ て設定して行った．使用燃料油は標準的な $\mathrm{A}$ 重油（比重 0. 85 )であり, 表 3 に示す標準的な運転条件を標準型弁 及び冷却弁について同一に保った。なお， $52 / 55 \mathrm{~A}$ 型機 関は独立送風源による過給を行っており，機関風量及び 給気圧力を実用機関（静圧過給）相当になるように設定 した．また，60MC型機関では $45 \%$ 舶用負荷以下で，電 動補助ブロアによる補助空気を使用している.

\section{表 3 機関運転条件 ( $100 \%$ M C R )}

\begin{tabular}{|l|c|c|}
\hline & $52 / 55 \mathrm{~A}$ & $60 \mathrm{MC}$ \\
\hline $\begin{array}{l}\text { Cooling water temp. } \\
\text { (valve cage in.) } \mathrm{K}\end{array}$ & 339 & 339 \\
\hline $\begin{array}{l}\text { Charge air temp. } \\
\text { (cylinder inlet) } \quad \mathrm{K}\end{array}$ & 316 & 303 \\
\hline $\begin{array}{l}\text { Specific air consumpt ion } \\
\mathrm{kg} / \mathrm{kWh}\end{array}$ & 7.07 & 8.84 \\
\hline $\begin{array}{l}\text { Exhaust gas temp. } \\
\text { (cylinder outlet) } \mathrm{K}\end{array}$ & 631 & 544 \\
\hline $\begin{array}{l}\text { Maximum cylinder } \\
\text { pressure }\end{array} \quad \mathrm{MPa}$ & 12.3 & 12.4 \\
\hline
\end{tabular}

計測は, 機関の一般性能及び図 3 に示した弁各部の温 度につき各負荷において行った，弁温度は，弁本体につ いては直径 $1.6 \mathrm{~mm}$ のシース熱電対（K型）を，その外 の部分においては $1.0 \mathrm{~mm}$ または $3.2 \mathrm{~mm}$ のあのを使用

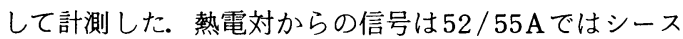
を直出しし，60MCではFMトランスミッターによって 取りだした後ペンレコーダまたはデータロガに記録した。 データの採取は, 負荷設定後 $(10-30$ 分) 機関性能及び 弁温度が定常となったことを確認して行った.

弁温度の計測に際し, バルブローテータの有無や, 弁 の位置（4 弁式の場合）が計測結果に影響する. 52/55 Aにおいては冷却弁と標準型弁を，機関運転条件一定の 下で同じ位置に装着して行い，計測の都合上弁の回転を 止めて燃料噴射弁に最む近い位置で弁フェースの温度

（U 3，V 3 ）を計測した. 60MCについてはバルブロ ーテータを装備し, 弁を回転させた状態で計測した。 


\section{5. 試験結果}

5.1 弁温度計測結果 $52 / 55 \mathrm{~A}$ における弁の代 表的温度の計測結果を図 4 , 及び図 5 に示す. 図 4 は, $70 \mathrm{H}$ 型冷却弁の計測結果を機関負荷に対して示した屯の で, 比較のため標準型弁の結果が破線で示されている. 機関負荷に対する標準型弁の温度変化は静圧過給機関に 特徵的なものとなっており，低負荷において高い温度を 示す. 最高温度は弁軸温度（U 4) を除いて $50 \% \mathrm{MCR}$ 付近で生じ, 弁底中央部計測点（U 1 ）において $882 \mathrm{~K}$ $\left\{609{ }^{\circ} \mathrm{C}\right\}$ が記録された. この時の弁フェース温度 (U

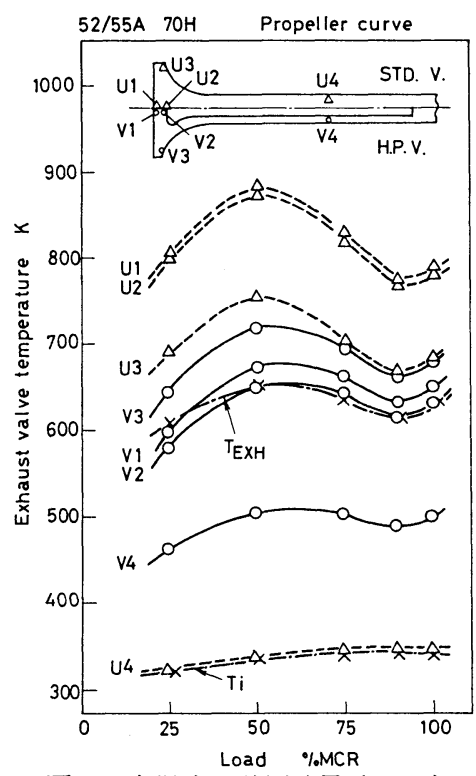

困 4 弁温度の計測結果 $(70 \mathrm{H})$

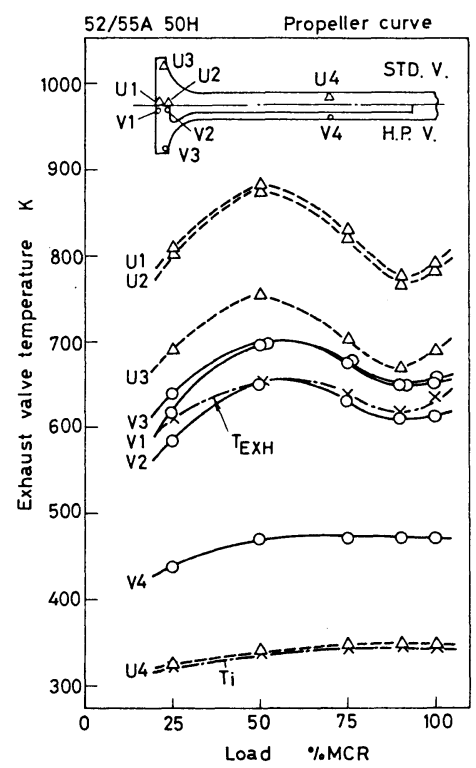

図 5 弁温度の計測結果 $(50 \mathrm{H})$
3) は $753 \mathrm{~K}\left\{480^{\circ} \mathrm{C}\right\}$ であった. 弁軸 (冷却部) 表面 温度（U 4) は, 前述のように軸部冷却熱抵抗を減少さ せたため, 冷却水温度より約 $5 \mathrm{~K}\left\{5^{\circ} \mathrm{C}\right\}$ 高い程度で, $100 \% \mathrm{MCR}$ で $345 \mathrm{~K}\left\{72^{\circ} \mathrm{C}\right\}$ となった. 一方, $70 \mathrm{H}$ 型 弁では弁底部温度（V1，V 2）の低下が著しく負荷全 域で $673 \mathrm{~K}\left\{400{ }^{\circ} \mathrm{C}\right\}$ 以下となり, 温度低下の比較的小 さいフェース温度（V 3 最高温度 $716 \mathrm{~K}\left\{443^{\circ} \mathrm{C}\right\}$ )を 下回って高温腐食を回避出来るレベルとなる，弁底部軸 方向温度差 ( V 1 - V 2) は, 標準型弁 ( U $1-\mathrm{U}_{2}$ ) の 2 倍以上であり, 弁底部から弁軸へ運ばれる熱量が増 加したことを示している. 弁軸表面温度（V４）は軸方 向への熱量が増加したため標準型弁よりも高く, 最高 $503 \mathrm{~K}\left\{230^{\circ} \mathrm{C}\right\}$ となる.この温度は, 低温腐食を防止 するのに十分なレベルであると思われるが, 弁軸と弁案 内の潤滑を考慮すると，屯う少し低い温度に制御する必 要があると考えられる. 弁軸温度を低下させるには, 弁 軸から冷却水に至る熱抵抗を減少させるか, 屯しくは後 述の $50 \mathrm{H}$ の計測結果から屯明らかなように, 弁軸へ流れ る熱量を制限すれば良い，図 5 は, 同じく $50 \mathrm{H}$ 型弁の温 度計測結果を示す. $70 \mathrm{H}$ と同様に弁底, 弁フェース共に 温度低下が見られるが, 弁底部の温度低下がやや小さく， 逆に弁フェース温度の低下が若干大きいため, 弁底 (V 1) とフェースの温度がほぼ等しくなっている. 弁底部, 弁フェース最高温度はともに $696 \mathrm{~K}\left\{423^{\circ} \mathrm{C}\right\}$, 軸部最 高温度は70Hより屯低く, $472 \mathrm{~K}\left\{199^{\circ} \mathrm{C}\right\}$ であった.

冷却の効果を更に詳しく見るために, 標準型弁との温 度差を機関負荷に対してとった結果を図 6 に示す。縦軸 の温度差は，一が温度の低下を，十が上昇を示す。図に よると, 弁底中央部 $\left(\Delta T_{1}\right)$, 弁フェース $\left(\Delta T_{3}\right)$ 共に 低負荷において温度低下が著しい事が分かる，弁底部温 度の低下は, 冷却室底部直径の大きい $70 \mathrm{H}$ が $50 \mathrm{H}$ に比へ

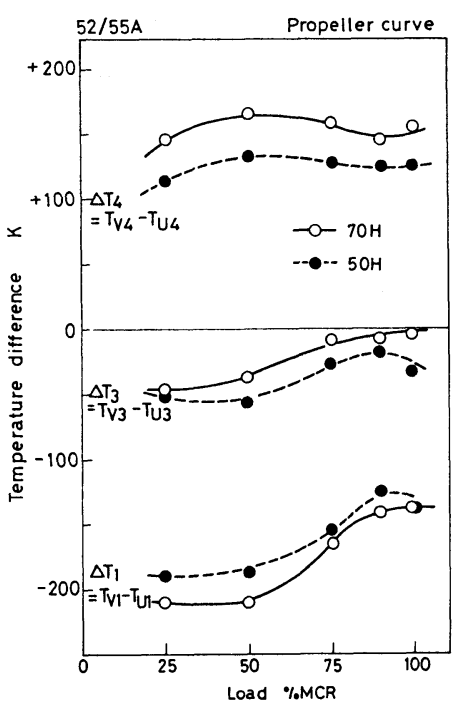

図 6 冷却能力の比較 $(52 / 55 \mathrm{~A})$ 
て負荷全域に渡って大きく, 50\% MC R以下で標準型弁 よりあ約 $210 \mathrm{~K}\left\{210{ }^{\circ} \mathrm{C}\right\}$ 低下する.このことは, 軸部 温度の上昇 $\left(\Delta T_{4}\right)$ が70Hにおいて $50 \mathrm{H}$ よりも大きくな っていることからあ分かるように, 弁軸へ運ばれる熱量 がより大きいことによるあのと考えられる. 一方, 弁フ ェース温度の低下は弁底部温度に比べて小幅であるが, $50 \mathrm{H}$ のほうがやや大きく, 50\% MCR以下の低負荷で約 $50 \mathrm{~K}\left\{50^{\circ} \mathrm{C}\right\}$ である. $50 \mathrm{H}$ 弁フェース冷却能力が70H を上回る理由としては, 冷却室底部直径の大きい $70 \mathrm{H} に$ おいては, かえって弁萊背面への放熱が阻害されること などが推測される.

図 7 および図 8 は, $60 \mathrm{MC}$ 型機関での弁温度計測結果

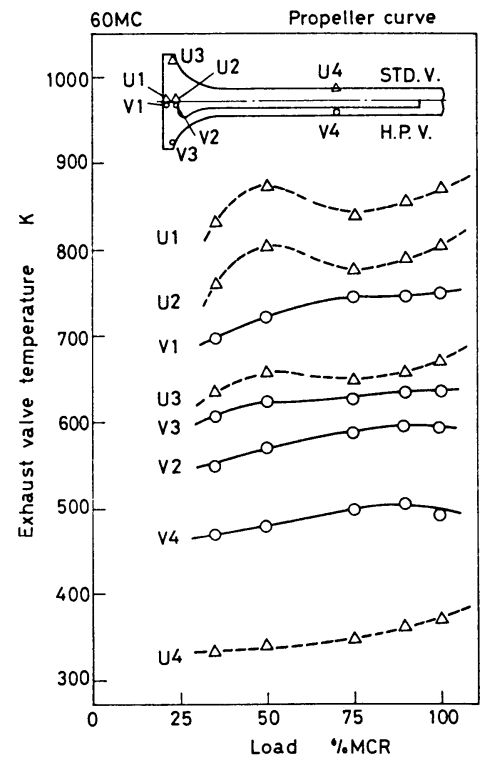

図 7 弁温度の計測結果 (60M C )

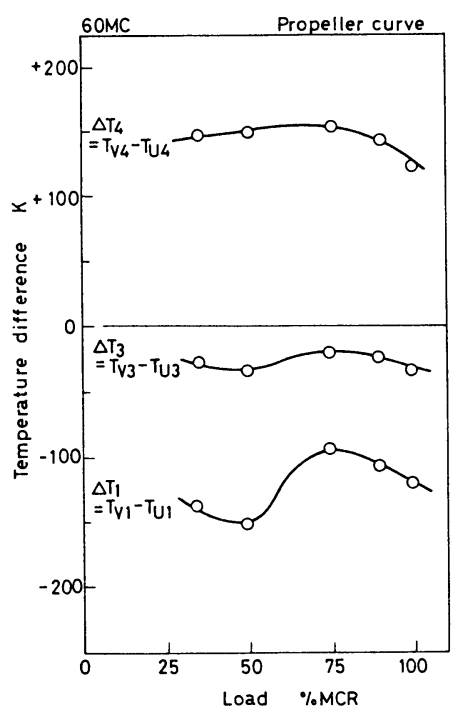

図 8 弁各部の温度低下 ( $60 \mathrm{MC}$ )
を示す. $52 / 55 \mathrm{~A}$ と同様に, 図 7 に機関負荷に対する弁 温度を, また図 8 には標準型弁との温度差を示す。標準 型弁の負荷に対する温度変化は52/55 A のあほど極端 でなく, 弁底部中央（U 1) では $50 \% \mathrm{MC} \mathrm{R}$ 付近で最高 温度 $873 \mathrm{~K}\left\{600{ }^{\circ} \mathrm{C}\right\}$ を示し, 弁フェース（U 3 ）にお いてはむしろ高負荷で高く $100 \%$ MCRで 667 K \{ 394 $\left.{ }^{\circ} \mathrm{C}\right\}$ となった. 冷却弁においては低負荷での温度ピーク が無くなり, 各部弁温度は負荷の上昇に対してほぼ単調 増加する. 最高温度は, 弁底中央部（V 1), 弁フェー ス（V 3 ) , 弁軸（V 4) で，それぞれ $749 \mathrm{~K}\left\{476{ }^{\circ} \mathrm{C}\right\}$ $632 \mathrm{~K}\left\{359^{\circ} \mathrm{C}\right\}, 503 \mathrm{~K}\left\{230^{\circ} \mathrm{C}\right\}$ である. 図 8 に示す 各部温度低下は, $52 / 55 \mathrm{~A}$ と同様に弁底部で最高 $152 \mathrm{~K}$ $\left\{152^{\circ} \mathrm{C}\right\}$ の大きな温度低下が, また弁フェースでは 20 〜35K \{20〜35 $\left.{ }^{\circ} \mathrm{C}\right\}$ の温度低下があり, 逆に弁軸部では 最高 $152 \mathrm{~K}\left\{152{ }^{\circ} \mathrm{C}\right\}$ の上昇が見られる. $52 / 55 \mathrm{~A}$ に比 べて弁軸温度の上昇の割りに弁底部温度の低下が小さい 理由としては, 弁の加速度などの冷却媒体に与える動的 な影響を別とすれば, 弁軸冷却熱抵抗の違いが大きいむ のと考えられる.

このように，冷却弁においては弁底中央部にて大きな 温度低下が見られるが, 弁傘部での熱の流れが変化する ことによってこの部分の場所的な温度分布が標準型弁と 異なったものとなっている可能性がある. 図 9 は60MC において, 弁底部の温度が最む高くなる50\% MC R で計 測した傘部温度分布を示す. 図によると, 弁底面の温度 は, 標準型弁では弁フェースに近い外周部に向かって下 がるのに対して，ヒートパイプ弁においては冷却室に近 い中央部で軸方向熱流束が大きいため温度が低く, 外周 で逆に高くなることが分る. 但し, 外周部においてもそ の温度は約 $773 \mathrm{~K}\left\{500{ }^{\circ} \mathrm{C}\right\}$ となって, 高温腐食に対し ては有利なレベルである.

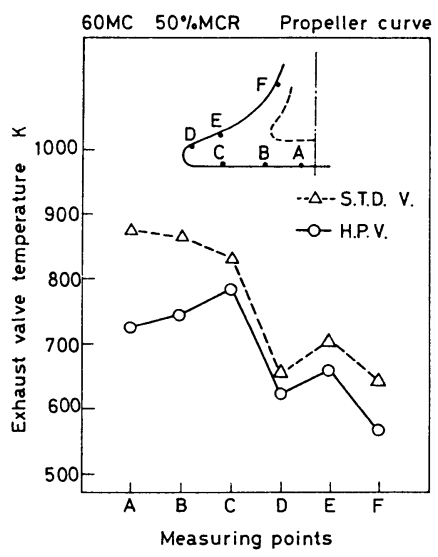

困 9 弁傘部温度分布

5.2 熱輸送量の評価このように弁軸の輸送熱 量の増加によって, 弁底部の温度低下と弁軸部の温度上 昇があたらされることが推測できたが，実機試験におい ては放熱経路が複雑で, 各部冷却水流量や温度を正確に 
把握できないために, 直接測定から弁座及び弁軸の輸送 熱量を評価することが難しい. そこで, 予め実施したモ デルテストの結果から, 弁ケージ内部での熱通過率, す なわち弁座から冷却水及び弁案内ブッシュから冷却水に 至る熱通過率を算出し, これを用いて弁座及び弁軸の輸 送熱量を推定した. すなわち，

$$
\begin{aligned}
& Q_{S E A T}=\mathrm{A}_{V} \cdot K_{K I} \cdot\left(T_{K}-T_{I}\right) \\
& Q_{S T E M}=\ell_{C} \cdot J_{G I} \cdot\left(T_{G}-T_{I}\right)
\end{aligned}
$$

但し，QSEAT，QSTEM はそれぞれ弁座及び弁軸輸送熱 量 ( $\mathrm{KW}), A v$ は弁シートの幾何学的接触面積 $\left(\mathrm{m}^{2}\right)$, $\ell_{C}$ は弁軸冷却長さ $(\mathrm{m}), K_{K I}, J_{G I}$ はモデルテストよ り求めた弁座〜冷却水および弁案内ブッシュ〜冷却水の 熱通過率 $\left(\mathrm{kW} / \mathrm{m}^{2} \cdot \mathrm{K}, \mathrm{kW} / \mathrm{m} \cdot \mathrm{K}\right), T_{K}, T_{G}, T_{I}$ は それぞれ弁座, 弁案内内面及び冷却水温度の実測值 $(\mathrm{K})$ である，52/55Aにおいて上記の計算を行った結果を図 10に示す. 図によると, 標準型弁ではこの計算に考慮さ れていない弁背面ガスへの放熱を無視すると, 熱量の 90 \%以上は弁座を通過することが分かる. 一方, $70 \mathrm{H}$ 型弁 においては弁軸へ運ばれる熱量QSTEMが大幅に増加し， 弁唑を通過する熱量 Q SEAT とほぼ同等かそれ以上となっ ており，これが弁底部温度の大幅な低下に寄与している ことが分かる. 但し, QSEATの絶対値は $50 \% \mathrm{MC} \mathrm{R}$ 以下 の低負荷では標準型弁に比べて減少するが, 高負荷にお いては大きな低下がなく, 図 6 に示した弁フェース温度 低下の傾向と一致する. 弁フェース及び弁底外周の温度 を更に低下させるには, 弁底外周部から冷却室へ向かう 熱流束を増して QSEATを低减することが必要である．例 えば, 弁フェース温度を $30 \mathrm{~K}\left\{30^{\circ} \mathrm{C}\right\}$ 低下させるために はQSEATを約 $10 \%$ 低减する必要があるが, ヒートパイプ の輸送可能熱量は十分大きいので, 冷却室底部の最適設 計によって十分可能と考えられる.

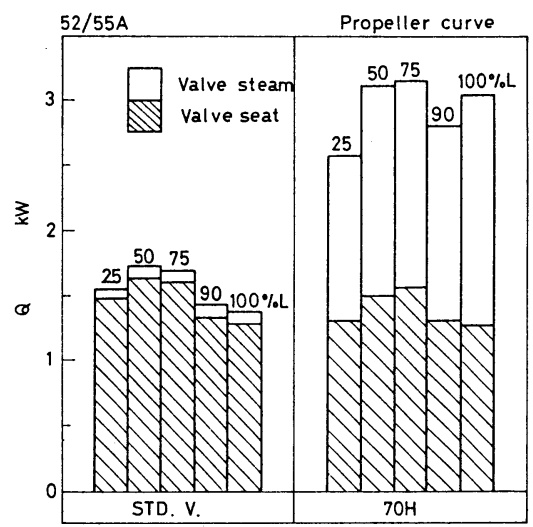

図10 輸送熱量とその内訳

図11は, 上で求めた弁軸輸送熱量 QSTEMを用いて次式 より算出した弁軸方向の総括熱通過率を示す.

$$
K S T E M=Q S T E M /\left(T_{B}-T_{F}\right)
$$

$K$ STEMは弁底面から弁軸冷却部に至る総括熱通過率 $(\mathrm{kW}$

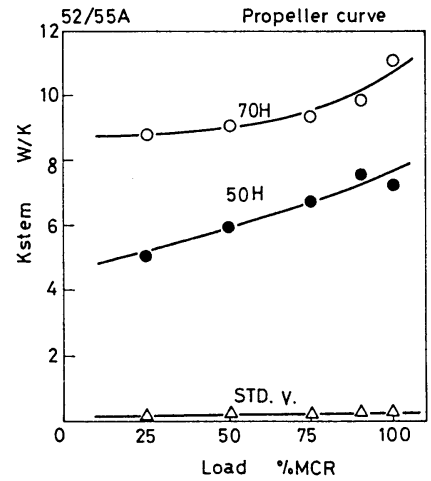

図11 弁棒の総括熱抵抗

（K）で, 弁底面と弁軸との温度差 $1 \mathrm{~K}\left\{1{ }^{\circ} \mathrm{C}\right\}$ あたり の輸送熱量を示し, $T_{B}, T_{F}$ はそれぞれ弁底面, 弁軸 (冷却部) の温度 $(\mathrm{K})$ である. 図から分かるように, ヒ 一トパイプ冷却によって KSTEMが熱伝導のみによって熱 を運ぶ標準型弁の30～50倍となっている．KSTEMが負荷 と共に増加するのは, ヒートパイプ内部での沸騰凝縮熱 伝達の温度依存性が表れたあのと思われる. また, $70 \mathrm{H}$ と50H の KSTEMの比較から, 冷却室底部面積が輸送熱量 に大きく影響することが分かる.

5.3 蒸気温度作動中のヒートパイプ内部での 蒸気温度は, 作動蒸気の量および王力を決め, 各種熱輸 送限界 $^{3)}$ および弁体の強度に影響を及ぼす重要な因子で ある. 実機試験では蒸気温度を直接計測することが困難 であるため,ここでは大まかな目安を得る意味で, 冷却 室底部における沸騰熱伝達率と, 弁軸内壁における凝縮 熱伝達率を等しいあのと仮定して蒸気温度を算出した. $52 / 55 \mathrm{~A}$ での計算結果は図12に示されており，70H，50 $\mathrm{H}$ ともに中程度の負荷で蒸気温度が最高となることが分 かる. $70 \mathrm{H}$ と $50 \mathrm{H}$ の比較では, 全般に $70 \mathrm{H}$ の蒸気温度が

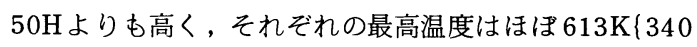
$\left.{ }^{\circ} \mathrm{C}\right\}$ と $573 \mathrm{~K}\left\{300^{\circ} \mathrm{C}\right\}$ である. これらの温度に対応する 飽和蒸気圧力は, それぞれ $14.7,8.8 \mathrm{MPa}\{150,90 \mathrm{kgf}$ $\left./ \mathrm{cm}^{2}\right\}$ であり, 低い值とはいえないが弁体の強度を損な

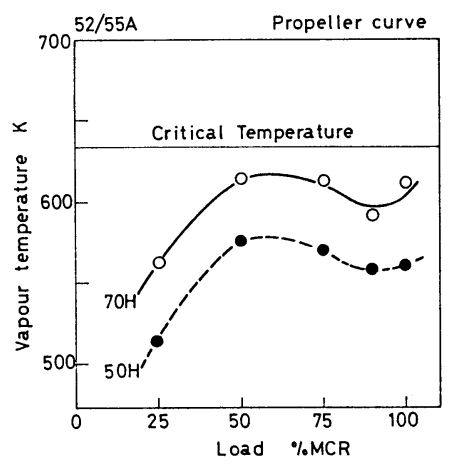

図12 蒸気温度推定結果 
うほどではない，むしろ，図中で示す臨界温度，すなわ ち封入された液がすべて蒸気となる温度に対して， $70 \mathrm{H}$ の余裕が小さくヒートパイプ動作の限界に近いことが問 題である. 5.1 で述べたように弁底部温度の低下が十分 で, 弁軸温度の上昇が過剩でないことを考え合わせると， 供試弁の中では $50 \mathrm{H}$ のほうが優れていると考えられる.

\section{6. むすひ}

排気弁の耐久性向上対策の一つとして，ヒートパイプ 方式を取り入れた冷却式排気弁を試作し，実機関による 性能試験を行ってその冷却性能を評価した。

その結果，次の事が明らかになった。

(1) ヒートパイプ邻却式排気弁においては弁軸へ輸送 される熱量が増加することによって，弁底部及び弁フェ 一ス温度が低下し，弁軸温度は逆に上昇する．52/55 A および60MC型機関における弁温度計測結果より，(ク弁 底部温度の低下が非常に大きく, $50 \% \mathrm{MC}$ R 以下の低負 荷で $150 \sim 210 \mathrm{~K}\left\{150 \sim 210^{\circ} \mathrm{C}\right\}$ であり高温腐食に対 して有利である. (1)弁フェース温度の低下は $25 \sim 50 \mathrm{~K}$ $\left\{25 \sim 50{ }^{\circ} \mathrm{C}\right\}$ と比較的小幅である. (方)弁軸は $473 \mathrm{~K}\{200$ ${ }^{\circ}$ C \} を越え，低温腐食を防止できる温度となる．等が分 かった.

（2）熱輸送量及び熱通過率の評価結果より，ヒートパ イプ冷却によって弁軸方向の熱通過率が標準型弁の30～ 50倍となって弁座を通過する熱量に匹敵する熱量が弁軸 に流れることが分かった，又，弁軸輸送燃量は冷却室低 部面積によって制御できる事あ判明した。

(3) 蒸気温度の推定結果によると, 作動中の最高温度 は70H，50Hでそれぞれ $613 \mathrm{~K}\left\{340^{\circ} \mathrm{C}\right\} ， 573 \mathrm{~K}\{300$ 'C \} である. 弁底, 弁フェースの泠却性能及び弁軸温度 の上昇度合いを勘案すると, 供試弁の中では $50 \mathrm{H}$ が優れ ていると判断できる.

これらの結果を総合すると, 弁棒の寸法制約の下で現 状の弁軸冷却を大きく変更しなくても，ヒートパイプの 熱輸送能力は十分であることが分った，従って，冷却室 への熱の流入経路を適切に制御すれば，弁各部の温度を 適正な範囲に保ち，高低温腐食の防止が図れるものと考 えられる。

\section{文献}

1）日本舶用機関学会材料強度研究委員会, 舶機誌， $18-10$ (昭 58-10), 778

2）山田・ほか 3 名，舶機誌，19-9(昭59-9)，764

3) H. Nguiyen-Chi, M. Groll, Heat Recovery Systems, vol. 1(1981), 275

\section{[質 疑 応 答]}

質問者 ヤンマーディーゼル(怢) 坂本正博

〔質問〕（1）図6でヒートパイプ冷却による排気弁の 温度低下が低負荷で大きくなっているが，その理由とし てどんなことが考えられますか。

(2) ヒートパイプ邻却方式の排気弁を設計するにあた って, 重要な設計因子としてはどのようなあのが考えら れるでしょうか.

[回答〕（1）52/55 A 4 サイクル機関では図 4 , 図 5 に示すように, 元来 $50 \%$ 負荷付近で排気温度及び排気弁 温度が高くなる静压過給機関の特徵的な様子を示してい る.これは高負荷で空気過㮃率が十分大きく，吹き报け 空気量による冷却効果が大きいために，中実弁では高負 荷で弁温度が低下しているあのと思われる。

然るに，ヒートパイプ弁ではヒートパイプによる輸送 熱量が非常に大きいため, 弁の温度はヒートパイプでほ とんど決まり，中実弁のような吹き抜け空気による影響 が少なく，負荷による弁温度の差は中実弁に比べて少な くなっている.

これらの中実弁とヒートパイプ弁の負荷に対する温度 特性の違いにより，吹き抜け空気による冷却効果の少な い低負荷でヒートパイプによる冷却効果が大きく出てい るものと考えられる.

（2）本文中の(3)式では $T_{B}$ は弁底面温度， $T_{F}$ は弁軸 (冷却部) 温度であるが，ヒートパイプ方式の排気弁設 計の原点に戻れば, 各々燃焼ガス温度, 冷却水温度と置 き換えてあよい，燃焼ガス温度が与条件として与えられ， 冷却水の温度を決定するとともに, 弁底板厚や冷却部の 構造等を決めると総括熱通過率が決まり，ヒートパイプ による輸送熱量が決まる。したがって，伝熱回路におけ る各部の温度も蒸気温度も求まり, 作動液を最終的に選 定することができる.

輸送熱量及び蒸気温度が設計上重要であるが，これは 上述のように冷却水温度及び各部の熱通過率で制御する ことができる，設計においては，弁底板，弁軸，ブッシ 工等の熱伝導に関する部分では, 材質より決まる熱伝導 率と設計寸法から, また沸騰, 凝縮, 対流熱卮達か問題 となる部分では理論式や経験式より熱通過率を推定して 熱輸送量及び各部温度とりわけ蒸気温度を適正な值とな るように設計する.

以上設計上の計算を主眼に述べたが，実際は各部の熱 通過率は単に材質や物性が決まれば単純に決まるあので ない，伝熱面皘や形状が変われば変化し, 温度分布, 熱 流束の状態が大きく変化するため, モデルテストや実機 テストによる温度計測により各部の熱通過率を正確に把 握する必要がある. 